\title{
Assessment of Concrete Mixes Replaced with Fly Ash and Reinforced with Steel and Polypropelene Fibres
}

\author{
S. Suresh, A. Sabarinathan
}

\begin{abstract}
This paper presents a series of tests for characterizing the structural behavior of fibre reinforced concrete subjected to different loading. The experimental program involves investigation of fly ash replaced concrete with two types of fibres i.e. Steel fibre and polypropylene fibre. Plain concrete and conventionally fly ash replaced reinforced concrete specimens have also been casted and tested in the laboratory. The mechanical properties of Conventional M30 grade of concrete and concrete with cement replaced by fly ash and reinforced with steel and polypropylene fibres of three volume fractions of $0.2 \%$ to $1.4 \%$ are studied. This research is to study about the mechanical properties of fly ash with steel and polypropylene as a strengthening material.
\end{abstract} fibre,

Keywords : Fly ash, Polypropylene, Reinforced concrete Steel

\section{INTRODUCTION}

Cement is a composite material which is comprised of filler and a folio. Run of the mill cement is a blend of fine total, coarse total, bond and water. Cement has numerous properties that make it a well known development material. The right extent of fixings, situation and restoring are required all together for these properties to be ideal. Both steel and polypropylene fibres have been used on reinforced concrete with partial replacement of fly ash and consequently increase its toughness and crack resistance. Fibre reinforced concrete can be used in some structural applications with a reduced amount or even without any conventional reinforcement.

\section{A. Objectives}

-The first objective of this research is to make a comparative study and to investigate the mechanical properties of reinforced concrete with cement replaced $30 \%$ by fly with Steel and Polypropylene fibres adding on concrete.

-To compare the properties of fly ash replaced conventional concrete with fibres added concrete (Steel and Polypropylene).

Revised Manuscript Received on December 05, 2019.

* Correspondence Author

Dr. S. Suresh*, Professor, Department of Civil Engineering, Sona College of Technology, Salem, Tamilnadu .Email: sansuresh86@yahoo.co.in.

A. Sabarinathan, Research Scholar, Anna University, Channai,

Tamilnadu. Email: write2sabaree@gmail.com

\section{LITERATURE REVIEW}

Nath sarker, (2011) demonstrated that the joining of fly cinder in cement diminished quality at the prior age when contrasted and control concrete. They additionally demonstrated that cements with $30 \%$ fly fiery debris have higher quality increase than those with $40 \%$ fly cinder and the quality of fly slag cements in both arrangement created at a higher rate than that of control solid stir as long as 56 days. They result comes as 40 to $50 \mathrm{~N} / \mathrm{mm}^{2}$ for $30 \%$ replaced fly ash, but for $40 \%$ replacement of fly ash results decrease as 38 to $29 \mathrm{~N} / \mathrm{mm}^{2}$. Ravichandran et al., (2009) detailed that the utilization of $80 \%$ steel strands and $20 \%$ polypropylene filaments at every volume division gives ideal mechanical properties and cross breed fibre of $2.0 \%$ volume portion with 80-20\% steel-polypropylene blend has progressively critical impact on mechanical properties. Okan karahan et al., (2005) revealed the expansion of polypropylene strands in cement somewhat improve in the compressive quality. At 28 years old days, the module of flexibility of cement containing $15 \%$ and $30 \%$ fly fiery debris were practically identical with the versatility modulus of control concrete. They noticed that there is no significant effect of fly ash on the modulus of elasticity. The expansion of $0.1 \%$ and $0.2 \%$ polypropylene filaments diminished the modulus of versatility esteems. Suj et al (2007) Experimental examination and expository displaying for flexural conduct Reinforced stringy solid bars utilizing engineered strands were performed by and extreme quality of steel fibre fortified self compacting solid pillars were tried by throwing $1.2 \mathrm{~m}$ since a long time ago strengthened solid bars utilizing self compacting concrete with steel filaments of three volume portions of $0.25 \%, 0.5 \%$ and $0.75 \%$. It is discovered that quality and malleability of fibre fortified self compacting solid examples have expanded considerably over traditional cement.

\section{. III. TESTING OF MATERIALS}

\section{A. Cement}

Standard Portland bond (53 grades) affirming to IS: 12269-1987 (reaffirmed in 2004) was utilized for all the solid blends. The properties of bond are given in table I. 
Table- I: Testing of Cement

\begin{tabular}{|c|l|c|}
\hline S.No & \multicolumn{1}{|c|}{ Description } & Result \\
\hline 1 & Specific gravity & 3.42 \\
\hline 2 & Fineness by sieve analysis & $5 \%$ \\
\hline 3 & Consistency & $36 \%$ \\
\hline
\end{tabular}

\section{B. Fine aggregates}

Regular waterway sand will be use as fine aggregate. The mass explicit gravity in stove dry condition and water assimilation of sand according to 2386 part III, 1963 (reaffirmed in 2002) are 2.61 and $1 \%$ individually. The qualities are referenced in table II.

Table-II: Testing of Fine Aggregates

\begin{tabular}{|c|l|c|}
\hline S.No. & Description & Result \\
\hline 1 & Specific gravity & 2.45 \\
\hline 2 & Water Absorption & $3.0 \%$ \\
\hline 3 & Fineness modulus & 2.86 \\
\hline 4 & Moisture content & $4 \%$ \\
\hline
\end{tabular}

\section{Coarse Aggregates}

Normally the totals possess $70 \%$ to $80 \%$ of the volume of cement and have a significant effect on its properties. Squashed stone of $20 \mathrm{~mm}$ down and held on $12.5 \mathrm{~mm}$ size is utilized for all the solid blends. Lab tests are directed and introduced in table III.

Table-III: Properties of Coarse Aggregates

\begin{tabular}{|c|c|c|}
\hline $\begin{array}{c}\text { S.No } \\
\cdot\end{array}$ & Description & Result \\
\hline 1 & Specific gravity & 2.75 \\
\hline 2 & Water Absorption & $2 \%$ \\
\hline 3 & Fineness modulus & 5.75 \\
\hline
\end{tabular}

\section{Fly Ash}

Class F fly ash is a mineral admixture having pozzolanic property. Based on a series of literature study, the fly ash is replaced by $30 \%$ of cement to obtain optimum results in both fresh and hardened concrete. The specific gravity of fly ash is 2.52. Table IV represents the chemical properties of fly ash.

Table-IV: Chemical Properties of Fly Ash

\begin{tabular}{|c|c|c|c|}
\hline S. No. & Compounds & $\begin{array}{c}\text { Fly ash } \\
\text { composition } \\
(\%)\end{array}$ & $\begin{array}{c}\text { Acceptable } \\
\text { Limits as per } \\
\text { IS 3812-2003 } \\
\text { part 1 (\%) }\end{array}$ \\
\hline 1 & $\mathrm{SiO}_{2}$ & $59.62 \mathrm{Min}$. & 35.0 \\
\hline 2 & $\mathrm{AlO}_{2}$ & 31.08 & -- \\
\hline 3 & $\mathrm{TiO}_{2}$ & -- & -- \\
\hline 4 & $\mathrm{Fe}_{2} \mathrm{O}_{3}$ & 2.92 & -- \\
\hline 5 & $\mathrm{MnO}$ & -- & -- \\
\hline 6 & $\mathrm{MgO}$ & $1.45 \mathrm{Max}$. & 5.0 \\
\hline 7 & $\mathrm{CaO}$ & -- & 1.74 \\
\hline 8 & $\mathrm{~K}_{2} \mathrm{O}$ & -- & -- \\
\hline 9 & $\mathrm{Na}_{2} \mathrm{O}$ & -- & $1.5 \mathrm{Max}$. \\
\hline 10 & $\mathrm{SO}_{3}$ & $0.51 \mathrm{Max}$. & 3.0 \\
\hline
\end{tabular}

\section{E. Water}

Consumable water which is accessible at the research center is utilized for blending of solid fixings and restoring of solid examples. Water from sources like industrial plants, sewage and other contaminated should not be used for concrete making.

\section{F. Polypropylene Fibre}

Monetarily accessible polypropylene fibrillated filaments of $12 \mathrm{~mm}$ long and $0.045 \mathrm{~mm}$ diameter are utilized with an aspect ratio of 266 in this research. The properties of polypropylene fibre are given in the table $\mathrm{V}$.

Table-V: Properties of Polypropylene Fibre

\begin{tabular}{|l|c|}
\hline \multicolumn{1}{|c|}{ Property } & Value \\
\hline Specific gravity & 0.91 \\
\hline Tensile strength, $\mathrm{MPa}$ & 750 \\
\hline Elastic modulus, $\mathrm{GPa}$ & 4.6 \\
\hline Water absorption & Nil \\
\hline Yield stress N/mm & 35 \\
\hline
\end{tabular}

\section{G. Steel Fibres}

Steel fibres of $0.4 \mathrm{~mm}$ diameter and $32 \mathrm{~mm}$ length with an aspect ratio of 80 were used in the present study. The characteristics of steel fibre is shown in table VI.

Table-VI: Properties of Steel Fibres

\begin{tabular}{|l|c|}
\hline \multicolumn{1}{|c|}{ Property } & Value \\
\hline Specific gravity & 7.8 \\
\hline Tensile strength, $\mathrm{MPa}$ & 280 \\
\hline Elastic modulus, $\mathrm{GPa}$ & 3.5 \\
\hline Water absorption & $\mathrm{Nil}$ \\
\hline Yield stress N/mm & 200 \\
\hline
\end{tabular}

\section{H. Super Plasticizers}

Super plasticizers or high range water reducing admixtures (HRWRA) are an important component of high performance concrete. In this research we are using the CONPLAST SP 600. The other admixtures including air entraining, quickening and impeding might be utilized similarly as in customary vibrated concrete yet counsel ought to be looked for from the admixture producer on use and the ideal time for expansion.

\section{CONCRETE MIX DESIGN}

The choice of reasonable elements of cement and the assurance of their relative extents were finished with an intend to create cement of required quality and toughness as conservative as would be prudent. In view of the properties of bond, fly fiery debris, fine total, coarse total and water, the blend extent was determined by embracing IS 10262 - 2009.

Mix Design for Conventional Concrete

Design stipulation:

- Characteristic compressive strength

- Maximum size of aggregate

$-30 \mathrm{~N} / \mathrm{mm}^{2}$.

- Degree of workability

$-20 \mathrm{~mm}$

- Degree of quality control

- 0.9 C.F.

- Type of exposure

- Good

- Mild

\section{A.Mix Proportion}

The mix proportion is arrived with the above design data using Indian standard recommendation and the mix ratio is arrived as 1:1.76:2.68 (cement: fine aggregate: coarse aggregate). With this ratio, 16 combinations of mixes were tried with varying proportions of Steel and Polypropylene fibres. For all the mix combinations, cement was replaced by fly ash at a 
constant rate of $30 \%$ by weight. The percentage variation of fibres was kept constant as $0.2 \%$ and the replacement was proceeded up to $1.6 \%$.

\section{EXPERIMENTAL TESTING}

Tests for Fresh Concrete are as follows.

- Slump Flow Test

- Compaction factor

\section{A.Slump Flow Test}

The concrete slump test is an empirical test that measures the workability of fresh concrete. More specifically, it measures the consistency of the concrete in that specific batch. This test is performed to check the consistency of freshly made concrete. Consistency is a term very closely related to workability. It is a term which describes the state of fresh concrete. It refers to the ease with which the concrete flows. It is used to indicate the degree of wetness. Workability of concrete is mainly affected by consistency i.e. wetter mixes will be more workable than drier mixes, but concrete of the same consistency may vary in workability. It is also used to determine consistency between individual batches. The test results are given in table VII.

Table-VII: Slump Test Results

\begin{tabular}{|c|c|c|}
\hline $\begin{array}{c}\text { Percentage of } \\
\text { fibres }\end{array}$ & $\begin{array}{c}\text { Initial Slump Value } \\
\text { with Steel Fibres }\end{array}$ & $\begin{array}{c}\text { Initial Slump Value with } \\
\text { Polypropylene Fibres }\end{array}$ \\
\hline 0.2 & 160 & 165 \\
\hline 0.4 & 140 & 165 \\
\hline 0.6 & 140 & 170 \\
\hline 0.8 & 130 & 170 \\
\hline 1.0 & 130 & 175 \\
\hline 1.2 & 125 & 178 \\
\hline 1.4 & 125 & 148 \\
\hline 1.6 & 120 & 148 \\
\hline
\end{tabular}

Tests for Hardened Concrete

To assess the presentation of various blend utilized in this work, following quality test were performed.

1. Compressive strength

2. Split tensile strength

3. Flexural strength

\section{B. Compressive Strength on concrete}

The compressive quality, as a standout amongst the most significant properties of solidified cement, when all is said in done is the trademark material incentive for arrangement of cement. 28 days 3D square compressive quality is tried on blocks of size $150 \mathrm{mmx} 150 \mathrm{~mm} \times 150 \mathrm{~mm}$ and 28 days compressive quality is tried and the outcomes are introduced in table VIII.

Table-VIII: Compressive Strength Results

\begin{tabular}{|l|c|c|c|}
\hline Mix Type & $\begin{array}{c}\text { Fibre } \\
\text { Composition } \\
(\%)\end{array}$ & $\begin{array}{c}\text { Average } \\
\text { Compressive } \\
\text { strength on 28 } \\
\text { days with steel } \\
\text { fibre }\left(\mathrm{N} / \mathrm{mm}^{2}\right)\end{array}$ & $\begin{array}{c}\text { Average } \\
\text { Compressive } \\
\text { strength on 28 } \\
\text { days with PP } \\
\text { fibre }\left(\mathrm{N} / \mathrm{mm}^{2}\right)\end{array}$ \\
\hline Mix 1 & 0.2 & 41.54 & 39.75 \\
\hline Mix 2 & 0.4 & 42.38 & 41.02 \\
\hline Mix 3 & 0.6 & 43.46 & 41.76 \\
\hline Mix 4 & 0.8 & 44.69 & 43.19 \\
\hline
\end{tabular}

\begin{tabular}{|l|l|l|l|}
\hline Mix 5 & 1.0 & 45.35 & 43.35 \\
\hline Mix 6 & 1.2 & 46.72 & 44.05 \\
\hline Mix 7 & 1.4 & 46.98 & 44.58 \\
\hline Mix 8 & 1.6 & 45.56 & 44.11 \\
\hline
\end{tabular}

\section{Split Tensile strength}

Three cylinder samples every one of the blend with different rates of $\mathrm{M}$-Sand were tried to decide the split elasticity following multi day utilizing a $2000 \mathrm{kN}$ Compression Testing Machine. The tests were led according to standard determinations. The test outcomes are organized in Table IX. It is seen that 28-day split elasticity increments upto $1.4 \%$ for steel and polypropylene fibre including the volume of cement.

Table-IX Compressive Strength Results

\begin{tabular}{|l|c|c|c|}
\hline Mix Type & $\begin{array}{c}\text { Fibre } \\
\text { Composition } \\
(\%)\end{array}$ & $\begin{array}{c}\text { Average split } \\
\text { tensile strength } \\
\text { on 28 days with } \\
\text { steel fibre } \\
\left(\mathrm{N} / \mathrm{mm}^{2}\right)\end{array}$ & $\begin{array}{c}\text { Average spilt } \\
\text { tensile strength } \\
\text { on 28 days with } \\
\text { PP fibre } \\
\left(\mathrm{N} / \mathrm{mm}^{2}\right)\end{array}$ \\
\hline Mix 1 & 0.2 & 3.324 & 3.34 \\
\hline Mix 2 & 0.4 & 3.437 & 3.57 \\
\hline Mix 3 & 0.6 & 3.517 & 3.77 \\
\hline Mix 4 & 0.8 & 3.616 & 3.98 \\
\hline Mix 5 & 1.0 & 3.73 & 4.21 \\
\hline Mix 6 & 1.2 & 3.99 & 4.58 \\
\hline Mix 7 & 1.4 & 4.37 & 4.37 \\
\hline Mix 8 & 1.6 & 4.11 & 3.99 \\
\hline
\end{tabular}

\section{$D$. Flexure Strength on concrete}

Three beam samples every one of the blend with different level of steel and polypropylene with fly cinder were tried to decide the flexural quality following 28 days utilizing a 30 Ton Universal Testing Machine. The tests were led according to standard determinations. The flexural quality of Concrete is given in Table X. It is seen that the 28-day flexural quality increments up to $1.6 \%$ of steel and polypropylene fibre including the volume of cement.

Table-X Flexure Strength Result

\begin{tabular}{|l|c|c|c|}
\hline Mix Type & $\begin{array}{c}\text { Fibre } \\
\text { Composition } \\
(\%)\end{array}$ & $\begin{array}{c}\text { Average flexural } \\
\text { strength on 28 } \\
\text { days with steel } \\
\text { fibre }\left(\mathrm{N} / \mathrm{mm}^{2}\right)\end{array}$ & $\begin{array}{c}\text { Average flexural } \\
\text { strength on 28 } \\
\text { days with PP } \\
\text { fibre }\left(\mathrm{N} / \mathrm{mm}^{2}\right)\end{array}$ \\
\hline Mix 1 & 0.2 & 6.2 & 8.02 \\
\hline Mix 2 & 0.4 & 7.5 & 9.38 \\
\hline Mix 3 & 0.6 & 8.77 & 10.5 \\
\hline Mix 4 & 0.8 & 9.8 & 11.69 \\
\hline Mix 5 & 1.0 & 10.11 & 12.5 \\
\hline Mix 6 & 1.2 & 13.65 & 13.33 \\
\hline Mix 7 & 1.4 & 15.02 & 14.55 \\
\hline Mix 8 & 1.6 & 18.0 & 16.21 \\
\hline
\end{tabular}

\section{E. Comparison of Test Results}

After conducting the mechanical properties of the specimens, a comparative study is performed to assess the performance of steel and polypropylene fibres and the results are plotted graphically in figure 1 , figure 2 and figure 3. 


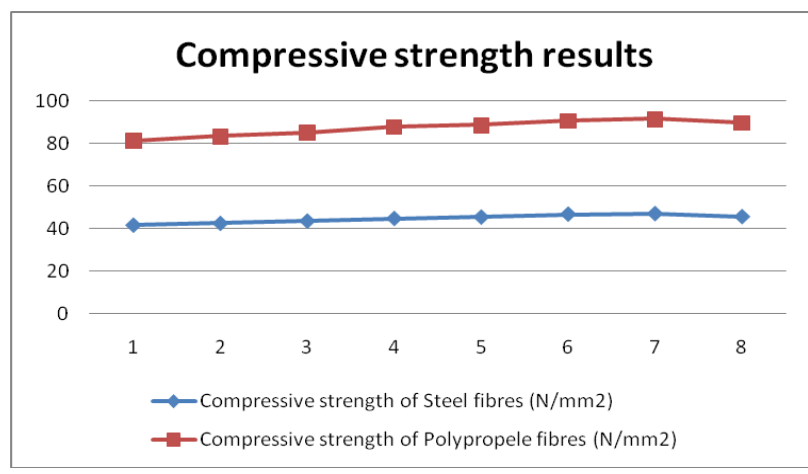

Fig. 1 Compressive strength pattern of steel and polypropylene fibres

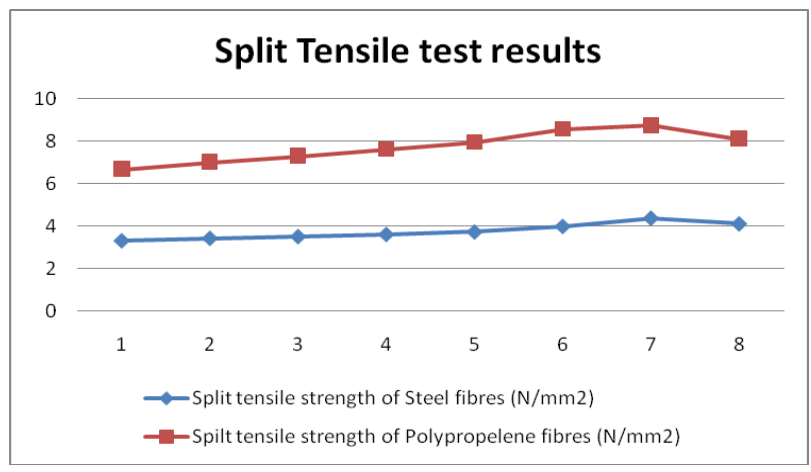

Fig. 2 Split tensile strength pattern of steel and polypropylene fibres

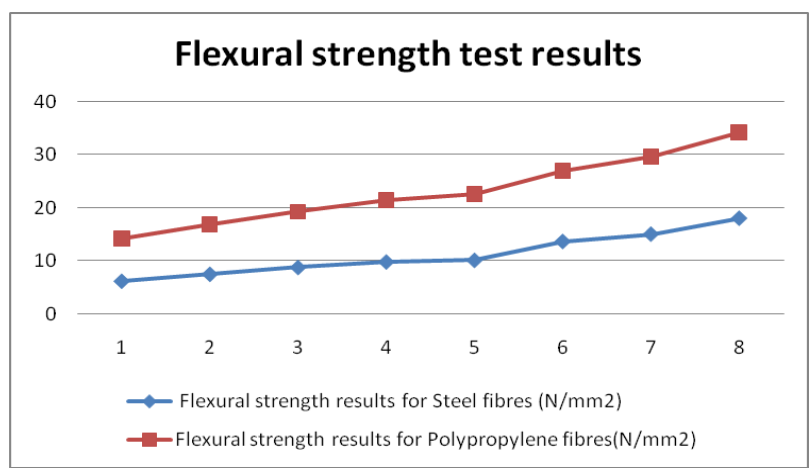

Fig. 3 Flexural strength pattern of steel and polypropylene fibres

\section{CONCLUSION}

From this experimental study, the following conclusions are summarized;

- The greatest increase in compressive quality for M30 was accomplished in $1.4 \%$ of both steel and polypropylene fibre with $30 \%$ of fly fiery remains traded for bond. There after increment in fibre substance has insignificantly decreased the compressive quality. The workability of concrete also get reduced by the addition of fly ash, which is required especially in higher percentages of steel and polypropylene fibres.

- The length and width of the crack is reduced due to the incorporation of fibres in the concrete.

- The Steel and polypropylene mix shows a slight increase in the compressive strength as compared with the plain concrete.

- The most extreme increase in split elasticity was accomplished for $1.2 \%$ polypropylene and steel fibre. Be that as it may, steel was got somewhat less worth contrasted with polypropylene.

- There after increment in fibre substance has barely decreased the part elasticity of both steel and polypropylene.

- From the present examination it is seen that the ideal dose of polypropylene fibre division is $1.2 \%$.

- The greatest addition in flexural quality was accomplished in $1.6 \%$ of polypropylene fibre.

- Steel and polypropylene fibre strengthened cement demonstrated increment in flexural quality when contrasted with typical fortified cement.

\section{REFERENCES}

1. Ahmed S.F.U, Maalej M., Paramasivam P (2007),"Flexural responses of hybrid steel-polyethylene fibre reinforced cement composites containing high volume fly ash" Construction and Building Materials,21 (2007), pp. 1088-1097.

2. Alhozaimy AM, Soroushian P, Mirza F. Mechanical properties of polypropylene fibre reinforced concrete and the effects of pozzolanic materials-1996.

3. Allan ML, Kukacka LE. Strength and durability of polypropylene fibre reinforced grouts. Cement Concrete Research 1995;25:511-21.

4. Aulia TB. Effects of polypropylene fibres on the properties of high-strength concretes. Lacer 2002;7:43-59.

5. Bisaillon,A., et al. (1994) "Performance of high-volume fly ash concrete in large experimental monoliths" ACI Mater. J. 912 pp. 178-187.

6. CEN - European Committee for Standardization. Steel fibre reinforced concrete test method for determination of first crack strength and ductility indexes.UNI 11039-2; 2003.

7. Chindaprasirt $P$, Homwuttiwong S, Sirivivatnanon V. Influence of fly ash fineness on strength, drying shrinkage and sulfate resistance of blended cement mortar,

8. Res 2004; 34: 1087-92.

9. Choi Y, Yuan RL. Experimental relationship between splitting tensile strength and compressive strength of GFRC and PFRC. Cement Concrete Res 2005.

10. Fanella DA, Naaman A. Stress-strain properties of fibre reinforced mortar in compression. ACI J 1985; 82(4):475-83.

11.G.R. Williamson, "The effect of steel fibres on compressive strength of the concrete," Fibre Reinforced Concrete, American Concrete Institute, Detroit, MI, (1974) pp. 195-207 (ACI).

12. Garg, M. and Singh, M, (1999 Cementitious binder from fly ash and other industrial wastes, Cement and Concrete Research, Volume 29, Issue 3, Pages 309-314.

13. H. Krenchel, S.P. Shah, Restrained shrinkage tests with polypropylene fibre reinforced concrete, in: S.P. Shah, G.B. Baston (Eds.), Fibre Reinforced Concrete and Applications, American Concrete Institute SP-105, Detroit, 1987, pp. 141-158

14. Karahan O. Properties of fibre reinforced fly ash concrete, Unpublished $\mathrm{PhD}$ thesis. Adana, Turkey: Cukurova University; 2006.

15. Karahan O, Tanyildizi H, AtisCD. Statistical analysis for strength properties of polpropylene fibre reinforced fly ash concrete. Concrete Research 2009; 61:556-62.

16. Kirca O, Sahin M. The influence of using polypropylene fibre on durability of white concrete. In: 5th National concrete congress, durability of concrete, Istanbul; 2003. p. 375-82.

17. Kawamata A., Mihashi H., Fukuyama H. (2003) "Properties of hybrid fibre reinforced cement-based composites." Journal of advanced concrete Technology, 1-3, Japan concrete institute, pp 283-290.

18. LI Bei-xing, Chen Ming-xiang Cheng Fang Liu Lu-ping. "The mechanical properties of Fibre Reinforced concrete", Journal of Wuhan University of Technology (May 2004) vol. 19 No.3

19. Machine Hsiea, Chijen Tua, P.S.Song, "Mechanical properties of polypropylene hybrid fibre-reinforced concrete", Material Science and Engineering A 494 (2008) 153-157.

20. Malhotra VM, Caretta AGG, Bilodeau A. Mechanical properties and durability of polypropylene fibre reinforced high-volume fly ash concrete for Shotcrete applications. ACI Mater J 1994;91:478-86. 
21. Malhotra, V.M.and Ramezanianpour, A.R. (1994), Fly ash in concrete, Energy Mines and Resources Canada, pp. 307.

22. Malhotra, V.M. (1994), - Dealing with High Volume Fly Ash Concrete, Advances in Concrete Technology (2nd ed.), CANMET, Ottawa, pp. 445-482.

23. Mostoufinezhad D, Hatami S. Effect of polypropylene fibres on cracking due to plastic shrinkage and workability of concrete. J Sch Eng 2004; 16:73-86.

24. Morgan DR, Mcaskill N, Carette GG, Malhotra VM. Evaluation of polypropylene fibre reinforced high-volume fly ash shotcrete. ACI Mater J 1992; 89:169-77.

25. Mokashi, A.Y (1995), Development of High Strength Concrete- using Fly Ash M.Tech. Thesis, Department of Civil Engg. IIT Delhi.

26. Narayanan R, Darwish IYS. Use of steel fibres as shear reinforcement. ACI Struct J 1987;216-226(May-June)

27. Neves RD, Fernandes de Almeida JCO. Compressive behaviour of steel fibre reinforced concrete. Struct Concr 2005;6(1).

28. Poon, C.S. et al.,(2000),A study on high strength concrete prepared with large volumes of low calcium fly ash Cement and Concrete Research Vol. 30 pp. $447-455$

29. Priyadarshi, A. K.(1999),-Use of fly ash as construction material, M.Tech. Thesis, Department of Civil Engg., IIT Delhi.

30. Ravichandran et al.P.N.(2009)," Strength Modeling of High-Strength Concrete with Hybrid Fibre Reinforcement",American Journal of Applied Sciences vol 6(2),

31. Rao, G. et al (1998), Thermal characteristics of a class F fly ash,Cement and Concrete Research, Volume 28, Issue 6 Pages 841-846.

32. Song PS, Wu JC, Hwang S, Sheu BC. Statistical analysis of impact strength and strength reliability of steel-polypropylene hybrid fibre-reinforced concrete. Construct Build Mater 2005; 19:1-9.

33. Sun Wei et al.(2003),॥Analysis of mechanism on water-reducing effect of fine ground slag, high-calcium fly ash, and low-calcium fly ash Cement and Concrete Research, Vol. 33 pp. 1119.

34. Salih SA, Al-Azaawee ME. Effect of polypropylene fibres on properties of mortar containing crushed bricks as aggregate. Eng Technology 2008; 26:1508.23

35. Topcu IB, Canbaz M. Effect of different fibres on the mechanical properties of concrete containing fly ash. Construction Build Mater 2007; 21(7).

36. Toutanji H, McNeil S, Bayasi Z. Chloride permeability and impact resistance of polypropylene-fibre-reinforced silica fume concrete. Cement Concrete Research 1998; 28:961-8.

37. Toutanji HA. Properties of polypropylene fibre reinforced silica fume Expansive-cement concrete. Construct Build Mater 1999; 13:171-7.

38. Wang C. Experimental investigation on behavior of steel fibre reinforced Concrete. MSc Thesis. University of Canterbury, New Zealand; 2006.

39. V M Malhortra, Carette, A Bilodeaue, "Mechanical properties and durability of Polypropylene fibre reinforced high-volume fly ash concrete for shotcrete applications", ACI Materials Journal,1994,91(5) 478-486.

40. T.S.Lok and J.R.Xiao, "Flexural strength assessment of steel fibre reinforced concrete," Journal of material in civil engineering, vol.11, No.3 (1999).

41. Yildırım SM, Ekinci CE. The effect of freeze-thaw on the steel, glass and Polypropylene fibre reinforced concrete. Sci Eng J Firat University2006

42. IS: 383-1970. "Specification for coarse and fine aggregate from natural sources concrete"

43. IS : 456-2000 " plain and reinforced concrete - code of practice"

44. IS: $2386-1963$, part I to VII " methods to test for aggregates for concrete"

45. IS516-1959(reaffirmed 1999) "method of tests for strength of concrete"

46. IS :5816-1999 "splitting tensile strength of concrete- method of tests"

\section{AUTHORS PROFILE}

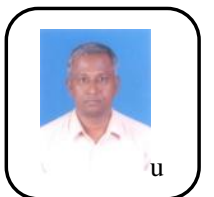

Dr. S. Suresh obtained his bachelor degree from M.K University, Madurai in the year 1992 and obtained his master degree from College of Engineering, Guindy, Chennai in the year 1996. With innovative thinking in research he joined as full time research scholar with UGC fellowship at Department of Civil Engineering, Indian Institute of science, Bangalore in the year 1997 and obtained his final graduation Ph.D in the year 2004. Dr S. Suresh has more than 20 years of teaching experience and published 23 International Journal papers and 26
International conference papers to his credit. At present he is guiding three $\mathrm{Ph} . \mathrm{D}$ research scholars at Anna University, Chennai and now he is working as professor, Department of Civil Engineering, Sona College of Technology, Salem-5. Dr. S. Suresh is a life member in Indian Society for Technica education (ISTE) and Life member Indian Water Works Association.

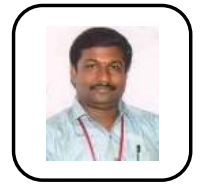

Sabarinathan A., Research Scholar, Anna University, Chennai. Completed B.E (Civil Engineering) first class in 2006, M.E (Infrastructure Engineering) first class in 2008 and carrying research work in the field of Fibre Reinforced Concrete. A life member in Indian Society for Technical education (ISTE) 